\title{
Functional properties of flour and starch from two cultivars of aerial yam (Dioscorea bulbifera) in South East Nigeria
}

\author{
${ }^{1}$ Ojinnaka, M.C., ${ }^{2}$ Odimegwu, E.N., ${ }^{1}$ Ilechukwu, R. \\ ${ }^{I}$ Department of Food Science \& Technology, Michael Okpara University of Agriculture Umudike, Abia State, \\ Nigeria \\ ${ }^{2}$ Department of Food Science \& Technology, Federal University of Technology Owerri, Imo State, Nigeria
}

\begin{abstract}
The functional properties and nutrient compositions of flour and starch from two cultivars of aerial yam (Dioscorea bulbifera) from south eastern Nigeria were investigated. Flour and starch were produced from two cultivars (purple and white) of aerial yam. The results of the proximate analysis showed that, the starch extract from the purple and white cultivars had relatively low values for fat ( $0.52 \%$ and $0.49 \%)$, protein $(0.81 \%$ and $0.13 \%)$, and ash (0.44\% and 0.48\%) as compared to the aerial yam flour. Crude fiber was not detected in the starch extracts. The starch extracts from the purple and white cultivars had highest carbohydrate content values of $91.92 \%$ and $92.92 \%$ respectively. The flour samples recorded lower bulk densities of $0.61 \mathrm{~g} / \mathrm{cm}^{3}$ and $0.57 \mathrm{~g} / \mathrm{cm}^{3}$ signifying it can be used for infant food formula production. The bulk densities for the starch samples were in the range $0.81 \mathrm{~g} / \mathrm{cm}^{3}-0.83 \mathrm{~g} / \mathrm{cm}^{3}$. The swelling capacity of the starch samples from aerial yam cultivars purple and white were higher than the flour samples with values $8.20 \%-8.24 \%$. The presence of fat and protein negatively affects the swelling power of starch. All the samples were found to be of high quality nutrient composition and functional properties which makes them excellent for varieties of product development.
\end{abstract}

Keywords: aerial yam, Dioscorea bulbifera, flour, starch

\section{Introduction}

Dioscorea bulbifera is an aerial yam also known with common names as potato yam, cheeky yam, bulbils- bearing yam. It is cultivated in the Southeast Asia, West Africa, South America and Central America. The wild form also occurs in both Asia and Africa. It is also known as Igname bulbifere, igname pousse enl air (France), brotwurzel, karotoffel-yam (Germany) Gaithi, karu-kunda, ratalu (Portugal), Inhame (Hindu). Whereas in Spanish speaking countries, it is called criollo (Venezuela) De Aire (Colombia); De Gunda, Volador (Cuba), papa Cimarrona (Mexico)" [1]. Aerial yam is known as Akam, Firigima and dundunbisa throughout the various regions of Ghana [2]. In south- eastern states in Nigeria it is known as "Adu" while in south- south Nigeria it is called "Odu".

Aerial yam is grown for its bulbis and eaten during famine season [2]. Though it possess a distinctive flavour and comparable in nutritional content to most preferred yams, it does not have the same appeal compared to D.alata and D.rotundata and so it is less studied and has high rate of post-harvest losses. In Nigeria aerial yam is almost going into extinction and it is counted among the underutilized plant species. Since aerial yam has received very low attention by food processors and consumers, this study seeks to investigate the functional properties and nutrient composition of flour and starch from two cultivars of aerial yam (Dioscorea bulbifera)- purple and white cultivars found mainly in south eastern Nigeria.

\subsection{Sample collection}

\section{Materials and Methods}

Two cultivars of aerial yam (purple and white cultivars) were purchased from National Root Crop Research Institute (NRCRI) Umudike Abia State

\subsection{Production of aerial yam into flour:}

The method described by Nwosu [1] was used in the flour production. The aerial yam bulbils were washed with clean water to remove adhering soil and other undesirable materials. The aerial yam samples (purple and white cultivars ) were then sorted, peeled and sliced into sizes of 2 to $3 \mathrm{~cm}$ in thickness. The slices were soaked in water while peeling to avoid enzymic browning and also to remove the bitter compound from the sliced samples. The slices were then blanched with hot water at $80^{\circ} \mathrm{c}$ for 8 mins after which the yam slices were transferred into the cabinet oven dryer to dry at $86^{\circ} \mathrm{c}$ for 4 hour. The dried yam slice were milled and screened through a $1 \mathrm{~mm}$ test sieve to obtain the powdery yam flour and then stored in an air tight container prior to analysis. 
Functional properties of flour and starch from two cultivars of aerial yam (Dioscorea bulbifera) in..

\subsection{Extraction of Aerial Yam Starch}

The wet extraction method described by Sanful and Engmann [3] was used for the starch extraction. The bulbis were washed, peeled, chopped into smaller pieces to facilitate grating. After peeling and grating, the samples were milled into a pulp. The pulp was collected into a cheese cloth in a colander mounted over a bucket and vigorously washed with water by hand. The fibre was squeezed to drain out the starch milk into the bucket. After the settling of starch granules, the supernatant was decanted and the wet starch open-airdried for $48 \mathrm{~h}$ and blended to a fine powder and stored for analysis.

\subsection{Nutrient Composition}

The aerial yam flour and starch samples were analyzed for moisture, ash, fibre, protein and fat contents according to the method of AOAC [4]. The carbohydrate content was determined by difference.

\subsection{Functional Properties 2.5.1 Bulk Density}

The method of Onwuka [5] was used. Bulk density of flour samples were determined by weighing the sample $(50 \mathrm{~g})$ into $100 \mathrm{ml}$ graduated cylinder, then tapping the bottom ten times against the palm of the hand and expressing the final volume as $\mathrm{g} / \mathrm{ml}$.

\subsubsection{Emulsion Capacity}

Emulsion capacity was determined according to A.O.A.C [6]. A flour sample (2g) and distilled water $(100 \mathrm{ml})$ were blended for 30sec at high speed of 100rpm. After complete dispersion, peanut oil was added from a burette in streams of about $5 \mathrm{ml}$. blending continued until there appeared separation into two distinct layers (emulsion breakpoint). Emulsion capacity was expressed as grams of oil emulsified by $1 \mathrm{~g}$ flour.

\subsubsection{Swelling Index Determination}

Three gram portions (dry basis) of each flour were transferred into clean, dry graduated $(50 \mathrm{ml})$ cylinders. Flour samples were gently leveled into it and the volumes noted. Distilled water (30ml) was added to each sample; the cylinder was swirled and allowed to stand for 60 minutes while the change in volume (swelling) was recorded every 15 minutes. The swelling power of each flour sample was calculated as a multiple of the original volume as done by Ukpabi and Ndumele [7].

\subsubsection{Viscosity}

The method of Onwuka [5] was adopted. Ten (10) percent of the flour was suspended in distilled water and mechanically stirred for $2 \mathrm{~h}$ at room temperature. Oswald type Viscometer was used to measure the viscosity.

\subsubsection{Gelation Capacity}

The method of Onwuka [5] was adopted in the determination of gelation capacity. A sample suspension of $2.20 \%(\mathrm{w} / \mathrm{v})$ in $5 \mathrm{ml}$ of distilled water was prepared in test tubes. The samples were heated for $1 \mathrm{~h}$ in a boiling water bath followed by rapid cooling under running cold tap water. The test tubes were then cooled further for $2 \mathrm{~h}$ at $4^{\circ} \mathrm{C}$. The gelation capacity is the least gelation concentration determined as the concentration when the sample from the inverted test tube will not fall or slip.

\subsubsection{Determination of $\mathrm{pH}$}

Ten grams of flour sample was weighed and dissolved in a beaker containing $25 \mathrm{ml}$ of distilled water to form slurry. It was allowed to stand for $10 \mathrm{~min}$ with constant stirring. The $\mathrm{pH}$ was then determined with a $\mathrm{pH}$ meter (R1 - 02895 HANNA / Italy).

\section{Results and Discussion}

\subsection{Chemical composition of flour and starch from two cultivars of aerial yam}

Table 1 shows the chemical composition of two cultivars of aerial yam flour and starch samples. The protein content obtained for the two cultivars of aerial yam (purple and white) were higher than those for the starch samples. Starch from the purple cultivar flour had protein content of $9.38 \%$ while the white cultivar had protein content value of $8.97 \%$. The purple and white cultivars had protein value of $0.81 \%$ and $0.13 \%$ respectively. The fat content of the aerial yam flour and starch samples were low though those of the flour samples were higher than the starch samples. Flour from the purple cultivar had the highest fat content of $1.68 \%$. The relatively low fat content and zero value obtained for protein in the starch extract are good, as the presence of these two components negatively affects the swelling property of starches [3]. The lower the values of these two components, the better the swelling and pasting properties of the starch extract [8]. There were no 
Functional properties of flour and starch from two cultivars of aerial yam (Dioscorea bulbifera) in..

crude fibre detected in the aerial yam starch samples but flour from the purple cultivar had higher fiber content of $1.38 \%$ while flour from the white cultivar had crude fiber content value of $1.28 \%$. The ash content of the flour from the purple and white cultivars were higher than those for the starch samples. The acceptable ash content of starch should be equal to or less than $0.2 \%$. [9]. The relatively low values of the ash and fibre content of the starch extract, positions it to exhibit good swelling and pasting properties. [10]. The moisture content of the starch samples were relatively low compared to the flour samples. The aerial yam flour had relatively high moisture, fat, ash, protein and fibre content than the starch extract. This is to be expected as the starch extract is devoid of other nutritional components [3]. The starch samples from purple and white cultivars had the highest carbohydrate values of $91.92 \%$ and $92.92 \%$ respectively while the flour samples had content value of $74.91 \%$ for the flour from purple cultivar and $76.55 \%$ for the white cultivar flour.

\subsection{Functional properties of flour and starch from two cultivars of aerial yam}

The results obtained for functional properties from the two cultivars of aerial yam flour and starch extracts are shown in Table 2. The starch samples from the aerial yam cultivars had higher bulk densities of $0.81 \mathrm{~g} / \mathrm{cm}^{3}-0.84 \mathrm{~g} / \mathrm{cm}^{3}$ for purple and white aerial yam cultivars compared to the flour samples which had bulk density values of $0.57 \mathrm{~g} / \mathrm{cm}^{3}$ and $0.61 \mathrm{~g} / \mathrm{cm}^{3}$ respectively. Bulk density of food increases with increase in starch content [11]. Ojinnaka et al. [12] in their work on the use of modified cocoyam (Xanthosoma sagittifolium) starch in cookie production reported packed bulk density of 0.67 and 0.62 for starch from native cultivars Ede Uhie and Ede ocha as well as loose bulk density of 0.49 and 0.47 for Ede uhie and Ede ocha respectively.The results of the bulk density shows that the flour samples from the two cultivars of aerial yam will be good for developing foods that require more protein while the starch extracts will be good for energy foods. The starch extracts from the purple and white aerial yam cultivars will exhibit better packaging properties than the aerial yam flour samples. Higher bulk density is desirable for greater ease of dispersibility and reduction of paste thickness [13]. Low bulk density of flour are good physical attributes when determining transportation and storability since the products could be easily transported and distributed to required locations [14]. Low bulk density is advantageous for the infants as both calorie and nutrient density is enhanced per feed of the child [15]. High bulk density is a good physical attribute when determining mixing quality of particulate matter [16].

The swelling capacity of the samples ranged from $7.47 \%-8.24 \%$. The study samples obtained lower values than reported by some root and tuber crops. This is an indication that the study samples have good swelling capacity. This is in agreement with the work done by Sanful and Engmann [3] who reported swelling power for aerial yam flour from Ghana as $7.19 \%$ while their starch extract had $8.19 \%$ swelling capacity. The values obtained in this work are higher than that obtained for $D$. rotundata varieties [17], and compares favourably with sweet potato varieties [18]. D. bulbifera starch can therefore be used in formulating weaning foods for infants, among other uses. The result from Table 2 shows that the swelling power of the starch extract was higher than that of the flour $(\mathrm{p}<0.05)$. This was to be expected as the concentration of starch granules was higher in the extract than the whole flour. The swelling power of starch is negatively affected by the presence of fat and protein in the sample [19] This may account for the observation made since the protein and fat contents of the aerial yam flour were higher than that of the starch extract.

The emulsion capacity for the starch and flour samples were in the range of $10.30 \%-11.70 \%$. The solubility of a protein is usually affected by emulsifying activity. This could be because of its hydrophilicity of hydrophobic balance, depending on the surface active agent, can form and stabilize the amino-acid composition, particularly the protein emulsion by creating electrostatic repulsion on oil surface [20].

The viscosity of the aerial yam flour and starch' was highest in the starch samples. This result is in agreement with the findings of Enwere [21] that legume flours have high viscosity under high temperature, which indicates that these flours are more resistant to swelling and rupture towards shear. The factors which may influence this property include the size and shape of the starch granules, presence or absence of fat and protein and perhaps molecular size and degree of branching of starch fractions[3]. As a result of high viscosity it can be incorporated in various food formulas in foods that require high thickening e.g. soups.

The $\mathrm{pH}$ values ranged between $6.04-6.17$ for the flour samples and $5.99-6.06$ for the starch samples. The $\mathrm{pH}$ is used primarily to calculate approximately consumption quality and hidden attributes of foods. Acids contribute to the post-harvest quality of foods like fruits as taste is primarily a balance between sugar and acid content, therefore post-harvest assessment of acidity is necessary in evaluating the taste of flours. This suggests the flour sample from the purple cultivar to be more acidic than the other samples.

The highest gelation capacity was recorded for the starch samples from cultivars white and purple which were in the range of $18.53 \%-18.73 \%$. This was closely followed by the flour samples from the purple and white cultivars which had up to $16.10 \%$ to $15.80 \%$ as their gelation capacity. There were significant differences in all the samples. Gelatinization affects digestibility and texture of starch containing foods, leaching amylase enhances susceptibility of starch to enzyme attack and the textural quality when starch is incorporated 
Functional properties of flour and starch from two cultivars of aerial yam (Dioscorea bulbifera) in..

in food products such as creams, soups, puddings, pie fillings and many sauces in viscosity [22]. It is also observed that gel forming capacity increased with increase in concentration of the starch samples [22].

\section{Conclusion}

The aerial yam flour was found to be higher in moisture, fat, ash, protein and fibre. Crude fiber was not detected in the starch samples. The carbohydrate values were higher in the starch samples than in the flour samples from the purple and white cultivars. The starch and flour samples have been found to have good functional and nutritional properties which can be of high importance in food manufacturing industries. However the purple cultivar exhibited better quality attributes than the white cultivar.

\section{References}

[1] N. Nwosu. Evaluation Of The Functional And Sensory Properties Of Biscuits Produced From Aerial Yam (Discorea bulbifera). International Science and Investigation Journal. 2(5), 2013, 1-17

[2] R.E. Sanful, I.Oduro and W.O. Ellis. Proximate and functional properties of five local varieties of aerial yam (Dioscorea bulbifera) in Ghana. Middle-East Journal of Scientific Research. 14(7), 2013, 947 -951

[3] R. E. Sanful and F. N. Engmann. Physico-Chemical and Pasting Characteristics of Flour and Starch from Aerial Yam. American. Journal of Food Science and Nutrition. 3(1), 2016, 1-7

[4] AOAC; Official Methods of the Association of Official Chemists. Official Analytical Int., Arlington, VA, (2000)

[5] G.I.Onwuka. Food analysis and instrumentation theory and practice (Napthali prints. Lagos. 2005)

[6] AOAC; Association of Official Analytical Chemists Official Methods of Analysis( 15th Ed, Gaithersburg. AOAC Press, USA, 1990).

[7] U.J. Ukpabi and C. Ndumele, C. Evaluation of the quality of garri produced in Imo State. Nigeria Food Journal 8, 1996. 103-110

[8] J. Blazek and L. Copeland. Pasting and swelling properties of wheat flour and starch in relation to amylose content. Carbohydrate polymers; 71(3), 2008, 380-387.

[9] I.C. Onwueme. The tropical tuber crop. J(ohn Wiley and Sons, Chinchester (UK), 1982, pp. 189-191.)

[10] M. Zhou, K. Robards, M. Glennie-Holmes and S. Helliwell. Structure and pasting properties of oat starch. Cereal Chemistry, 75(3) $1998,273-281$

[11] S.M.Bhattacharya and Prakash.. Extrusion blends of rice and chicken pea flours: A response surface analysis. J. Food Eng., 21 (1994), 315-330.

[12] M.C.Ojinnaka, E.N.T. Akobundu and M.O. Iwe. Cocoyam starch modification effects on functional, sensory and cookies qualities. Pak. J. of Nutr. 8(5) 2009.558-567.

[13] A. Udensi and O. Eke. Proximate composition and functional properties of flour produced from Mucuna cochinensis and Mucuna utles. In Proceedings of the 1st Annual Conference of the College of Agriculture and Veterinary Medicine Abia State University. 10-13th Sept.2000.Pp 170-174.

[14] S.O. Agunbiade and M.O. Sanni. The effect of ambient temperature of cassava tubers on Starch quality. Pp 180-194. In: Root Crops. The small processor and development of Local Food Industries for market economy. Proceedings of the Eight Triennials Symposium of the International Society for Tropical Root Crops. African Branch (ISTRC-AB) 12-14 Nov. (2003) IITA, Ibadan Nigeria.

[15] A.I.Onimawo and K.M. Egbekun. Comprehensive Food Science and Nutrition. (Revised edn Grace foundation pub. Jos. 1998)

[16] N.J. Lewis. Physical properties of processing systems.( Hartnolls Ltd Bodman, Cornwall, Great Britain 1990).

[17] R.N.A.Addy, F.D. Wireko-Manu and I. Oduro. Physicochemical and Pasting Properties of Starch Extracted from Four Yam Varieties. Journal of Food and Nutrition Sciences, 2(6), 2014, 262-269

[18] H. Kusumayanti, N.A.Handayani andH. Santosa. Swelling power and water solubility of cassava and sweet potatoes flour. Procedia Environmental Sciences 23, 2015, 164-167.

[19] J. Bjorck, A.C.Eliasson and A. Drews. Some nutritional properties of starch and dietary fiber in barby different levels of amylose. Cereal Chemistry, 67(4) 1990, 327-333.

[20] I.E.Moure,A. Francis and I.U. Anumnu .Thesis B.Tech on the Effect of Emulsion Capacity on Legumes Flour. (University of Port Harcourt. Pp.20:40. (2006)

[21] S. Enwere. The Effect of Heat Treatment on Selected Functional Properties of Cowpea Flour Tropical Sci 26, 1986, 223-272

[22] J.E. Rickard. Quality aspects of tropical root crop starches. In: 9th Symposium. Int. Soc. Trop. Root Crops, Ghana 1991.

[23] O.S. Lawal, K.O. Ago-Iwoye, R.A. Adebowale and Oderinde. Functional Properties of amylopectin and amylose fractions isolated from Bambarra groundnut (Voandxeia subterranean) starch. Afr. J. Biotechnol., 3: 2004.399-404.

Table 1. Proximate Composition Of Flour And Starch From Purple And White Cultivars Of Aerial Yam (\%)

\begin{tabular}{|l|l|l|l|l|l|l|}
\hline Samples & Moisture & Ash & Fat & Crude protein & Crude fibre & Carbohydrate \\
\hline Purple Cultivar Flour & $9.91 \pm 0.02$ & $2.74 \pm 0.03$ & $1.68 \pm 0.01$ & $9.38 \pm 0.02$ & $1.38 \pm 0.02$ & $74.91 \pm 0.02$ \\
\hline White Cultivar Flour & $9.47 \pm 0.48$ & $2.56 \pm 0.02$ & $1.60 \pm 0.01$ & $8.97 \pm 0.02$ & $1.28 \pm 0.01$ & $76.129 \pm 0.07$ \\
\hline Purple Cultivar Starch & $6.31 \pm 0.01$ & $0.44 \pm 0.01$ & $0.52 \pm 0.01$ & $0.81 \pm 0.01$ & - & $91.92 \pm 0.02$ \\
\hline White Cultivar Starch & $5.98 \pm 0.02$ & $0.48 \pm 0.01$ & $0.49 \pm 0.01$ & $0.13 \pm 0.01$ & - & $92.92 \pm 0.02$ \\
\hline
\end{tabular}

TABLE 2: Functional Properties Of Flour And Starch From Purple And White Cultivars Of Aerial Yam

\begin{tabular}{|c|c|c|c|c|c|c|}
\hline Samples & $\begin{array}{l}\text { Bulk density } \\
\left(\mathrm{g} / \mathrm{cm}^{3}\right)\end{array}$ & $\begin{array}{l}\text { Gelation } \\
(\%)\end{array}$ & $\begin{array}{l}\text { Emulsion } \\
\text { capacity }(\%)\end{array}$ & $\begin{array}{l}\text { Swelling } \\
\text { capacity }(\%)\end{array}$ & $\begin{array}{l}\text { Viscosity } \\
\text { (Cp) }\end{array}$ & pH \\
\hline Purple Cultivar Flour & $0.613 \pm 0.01$ & $16.10 \pm 0.10$ & $10.30 \pm 1.00$ & $7.58 \pm 0.01$ & $234.00 \pm 0.53$ & $6.17 \pm 0.02$ \\
\hline White Cultivar Flour & $0.573 \pm 0.01$ & $15.80 \pm 0.10$ & $11.37 \pm 0.15$ & $7.47 \pm 0.02$ & $240.43 \pm 0.67$ & $6.04 \pm 0.02$ \\
\hline White Cultivar Starch & $0.837 \pm 0.01$ & $18.73 \pm 0.06$ & $11.70 \pm 0.10$ & $8.24 \pm 0.01$ & $495.43+0.40$ & $5.99 \pm 0.06$ \\
\hline
\end{tabular}

